\title{
ПЕРСПЕКТИВНІСТЬ ЗАСТОСУВАННЯ НОВІТНІХ ТА “ЗАБУТИХ” МЕТОДІВ ВИКЛАДАННЯ ФАРМАКОЛОГІЇ У ВИЩІЙ ШКОЛІ
}

\author{
Н. І. Волощук, О. С. Пашинська, О. В. Грималовська \\ Вінницький національний медичний університет імені М. І. Пирогова
}

\section{PROSPECTS OF APPLICATION OF NEW AND “FORGOTTEN” METHODS OF TEACHING PHARMACOLOGY IN HIGH SCHOOL}

\author{
N. I. Voloshchuk, O. S. Pashynska, O. V. Hrymalovska \\ M. Pyrohov Vinnytsia National Medical University
}

\begin{abstract}
У статті розглянуті роль та місце деяких прийомів запам'ятовування великої кількості матеріалу на кафедрі фармакології Вінницького національного медичного університету ім. М. І. Пирогова як дієвої допоміжної форми для збільшення обсягу пам'яті, засвоєння студентами знань, набуття умінь та навичок навчального процесу. Запропоновані мнемотехнічні методи, одним із яких є акроніми, органічно вписуються в педагогічний процес, сприяють економії часу студентів, доповнюють та урізноманітнюють викладання, а також відповідають умовам педагогічного середовища вищих навчальних закладів.
\end{abstract}

The article considers the role and position of some methods of memorizing large amounts of material at the Department of Pharmacology of M. Pyrohov Vinnytsia National Medical University, as an effective supplemental forms to increase the amount of memory the mastering of knowledge, acquisition of skills of the educational process. There were proposed mnemotechnical methods, one of which is acronyms, fit perfectly into the pedagogical process, help to save time of students, complement and diversify the teaching and to meet the conditions of educational environment of higher education.

Вступ. Інновації в освіті - це процес створення, впровадження та поширення в освітній діяльності нових підходів, ідей, методів та прийомів, технологій, спрямованих на оновлення, модернізацію, трансформацію навчального процесу відповідно до вимог часу [1]. Зокрема для вищої школи визначальним має бути формування у студентів системного підходу до аналізу професійних завдань, стратегічного мислення, здатності до соціальної мобільності, прагнення до самонавчання, самовиховання та самовдосконалення впродовж усього активного трудового життя. Згідно з представленим проектом Стратегії реформування вищої освіти в Україні до 2020 року цього можна досягнути, в тому числі і за рахунок постійної імплементації інноваційних методів у навчальний процес вищої школи [2].

Важливою проблемою дидактики вищої школи $€$ обгрунтування і розробка методів викладання i навчання студентів. Підготовка і формування фахівця у вищій школі не можливі без застосування ефективних і гнучких методів навчання і виховання [3]. Які ж конкретні методи викладання і навчання студентів вищої школи зараз використовуються в

(с) Н. І. Волощук, О. С. Пашинська, О. В. Грималовська практиці? Вища школа нагромадила і практично випробувала велику кількість методів, яким можна дати таку класифікацію:

1. Методи, що забезпечують сприймання і засвоєння знань студентами. Це такі добре відомі методи, як лекції, самостійна робота студентів 3 книгою, консультації викладачів, сприймання телепередач і т. ін.

2. Методи застосування знань і набуття умінь та навиків. Це семінарські та практичні заняття, лабораторні роботи, контрольні завдання, тренувальні заняття в кабінеті програмованого навчання, праця в клініці, проведення навчальної і виробничої практики, курсові та дипломні роботи [4].

Зрозуміло, що цей поділ відносний. Методи першої групи не тільки дають можливість сприймати і засвоювати знання, формувати поняття, але й сприяють закріплюванню знань, набуттю інтелектуальних навиків. А свідоме і творче використання методів другої групи дозволяє студентові не тільки закріплювати знання і виробляти уміння і навики навчальної та професійної діяльності, але й допомагають поглиблювати знання, діставати додаткові відомості. 
Окремо слід сказати про допоміжні засоби навчання. До них можна віднести застосування технічних засобів (інтернет, кіно, телебачення, радіо тощо) і програмоване навчання. Використання і застосування методів викладання і навчання - творчий процес. Проте це не свідчить, що діяльність кафедри полягає тільки в щорічному створенні нових та несприйнятті або невикористанні більш давніх методів викладання. Творчість і педагогічна майстерність, на нашу думку, полягають саме у мистецтві застосування різних методів у конкретних умовах і для досягнення певної дидактичної мети.

Основна частина. Творче використання існуючих методів не виключає створення нових методів та прийомів викладання і навчання. Психологією і педагогікою вже давно доведено, що різноманітність методів повніше відповідає природі відчуттів і сприймань студента, дозволяє більш повно і точно розкрити властивості фактів і явищ, що вивчаються, і дає більше можливостей для творчої діяльності студентів у навчальному процесі. Навчальний процес динамічний за своєю суттю: розвивається наука, виникають і розв'язуються нові проблеми, збагачується педагогічний досвід, формується світогляд студентів. Все це примушує педагога постійно вдосконалювати і збагачувати навчальний процес [5, 6]. При вивченні курсу фармакології з кожним роком зростає кількість інформації, яку необхідно запам'ятовувати. Для поліпшення цієї задачі в сучасній методиці викладання можна застосовувати мнемотехнічні прийоми, які несправедливо забуті на сучасному етапі [7].

Пам'ять - це процес запам'ятовування, збереження й наступне відтворення інформації. Для запису інформації на згадку необхідно надати думкам упорядковану структуру. Будь-яка організація матеріалу, що запам'ятовується, полегшує роботу пам'яті. Особливо ефективні мнемотехнічні прийоми (прийоми запам'ятовування), тому що наявність у пам'яті слідів - “розпізнавальних знаків”, або “адрес”, набагато спрощує доступ до них. Ефективність запам'ятовування й збереження в пам’яті певного предмета, тексту або явища залежить від особливостей їхньої побудови або організації, які зазвичай виявляє людина в процесі запам’ятовування. Саме організуюча розумова діяльність і емоційні прояви, що супроводжують сприйняття, лежать в основі запам'ятовування матеріалу і його подальшого відтворення [8]. Різноманітність прийомів запам'ятовування не тільки підвищує ефективність запам’ятовування, але і створює позитивний емо- ційний настрій. Одним із таких відомих, але дещо “забутих” прийомів є мнемотехніка.

Мнемотехніка (гр., мистецтво запам’ятовування)система особливих способів, що полегшують запам'ятовування й збільшують обсяг пам'яті [9]. Мнемотехніка відома $з$ давніх часів і нараховує як мінімум дві тисячі років. Вона була об’єктом наукового дослідження багатьох вчених.

Одним із прийомів мнемотехніки, що одержав особливе поширення в останні десятиліття в зв'язку зі зростаючою тенденцією до економії часу, акроніми. Він полягає в складанні скорочених назв з перших букв. Наприклад: СНД, ЮНЕСКО, $\mathrm{OOH}, \mathrm{HATO}$. Мнемотехніка $є$ досить доцільною у навчанні майбутніх лікарів. Відомо, що студентаммедикам необхідно запам'ятовувати величезну кількість інформації. Слід зауважити, що одна справа пам'ятати інформацію до певного дня (іспиту), інша - засвоїти назавжди зі змогою аналітичного творчого відтворення та використання у практичній діяльності. У першому випадку, після того як іспит пройде, вивчене швидко починає забуватися. Тому головний акцент у підготовці фахівців ми ставимо на довготривале запам'ятовування. В клінічних умовах лікарям доводиться швидко, інколи миттєво приймати необхідні рішення та застосовувати життєво важливі засоби для спасіння хворих. Тому вже на третьому курсі, при вивченні фармакології викладачі намагаються формувати у студентів “автоматичне” розуміння алгоритмів надання медикаментозної допомоги при різноманітних станах. Для цього студенту необхідно за короткий термін одночасно швидко представити патогенез захворювання, визначитись з препаратами, які необхідно застосувати, а також пригадати дозу та шлях введення в кожному конкретному випадку.

Для покращення адаптації щодо розв'язання таких ситуацій найбільш ефективним способом полегшення довільного запам'ятовування $є$ створення потрібної установки. Установка на запам'ятовування створюється за допомогою самоінструкції, спрямованої на досягнення необхідної повноти, точності або міцності запам'ятовування. Вона впливає не тільки на сам факт запам'ятовування, а й на тривалість збереження [10]. Тому ми вирішили створити наочні моделі надання допомоги при найбільш поширених невідкладних станах. Використали надбання колег з методикою залучення акронімів. Як приклад можна навести фармакотерапію деяких невідкладних станів. 
Лікування ішемічної хвороби серця

A - Acetylsalicylic acid and Antianginal therapy

B - B-blocer and Blood preasure

C - Cholesterol and Cigarettes

D - Diet and Diabetes

E - Education and Exercise
Застосування акронімів при вивченні фармакології було винесено як тему для самостійної індувідуальної роботи студентів, результати якої доповідались у вигляді постерної доповіді на науковій конференції студентів та молодих вчених. Ця доповідь стала призером у своїй номінації, а інтерес до такої інформації спонукав викладачів кафедри продовжити роботу в цьому напрямку.

\begin{tabular}{|c|c|}
\hline \multicolumn{2}{|c|}{ Легкі алгоритми для лікування важких станів } \\
\hline ЛІКУВАННЯ ГОСТРОЇ СЕРЦЕВОЇ НЕДОСТАТНОСТІ & ЕКСТРЕНА ДОПОМОГА ПРИ НАБРЯКУ КВІНКЕ \\
\hline U - Upright Position & П- Преднізолон 60-90 мг в/м чи в/в, \\
\hline N - Nitrates & зменшує проникність капілярів, \\
\hline L - Lasix & зумовлену вивільненням гістаміну; \\
\hline O-Oxygen & Л - Лазикс (фуросемід) 40-80 мг в/в в 10- \\
\hline A - ACE Inhibitors & 20 мл фізрозчину, прискорюе \\
\hline D - Digoxin & виведення алергену із організму; \\
\hline F - Fluids (Decrease) & А - Адреналін 0,1-0,5 мл 0,1\% розчину \\
\hline A - Afterload (Decrease) & п/ш, при зниженні АТ та асфіксіі; \\
\hline S - Sodium Restriction & К - Контрикал 30000 ОД в/в в 300 мл \\
\hline T - Test (Potassium Level) & фізрозчину, проявляє \\
\hline $\begin{array}{l}\text { ЛІКУВАННЯ АЛЕРГІїЗА АНАФИЛАКТИЧНИМТИПОМ } \\
\text { (КРОПИВНИЦІ) }\end{array}$ & $\begin{array}{l}\text { аптипротеолітичнудію, } \\
\text { використовують для профілактики }\end{array}$ \\
\hline Г- Глюкокортикоїди & шоку; \\
\hline $\begin{array}{l}\text { А- Антигістамінні лікарські препарати }\left(\mathrm{H}_{1} \text { - }\right. \\
\text { блокатори) }\end{array}$ & $\begin{array}{l}\text { C - Сальбутамол (не більше 1-2 } \\
\text { інгаляцій!!!), для збільшення просвіту }\end{array}$ \\
\hline Д- Десенсибілізуючі препарати & $\begin{array}{l}\quad \text { дихальних шляхів; } \\
\text { А-Амінокапронова кислота 5\%-200мл }\end{array}$ \\
\hline ТЕРМІНОВЕ ЛІКУВАННЯ ІНФАРКТУ МЮКАРДА & в/в крапельно, потім - по 100 мл через \\
\hline M-Morphine hydrochloride & 4 год або по 4 гр. per os $4-5$ разудень \\
\hline o- Oxygen & до повного купірування реакції, для \\
\hline $\mathrm{N}$ - Nitroglycerinum & профілактики тромбоутворення й \\
\hline A-Aspirin & тромбоемболії. \\
\hline
\end{tabular}

I ще хочеться поділитися одним нашим новим “старим” надбанням.

У багатьох університетах Великої Британії на цей час дуже поширені так звані навчальні пакети, які містять навчальні посібники, книги-зошити для індивідуальних занять, що спираються на ідеї алгоритмізації навчання. Такі навчальні посібники поділяються на окремі “модулі”, студенти можуть їх самостійно заповнювати, відповідаючи на запитання. “Модулі” містять матеріал різного ступеня складності для студентів, які мають різну підготовку і здібності. До пакетів входять відеодиски, серії слайдів тощо. Навчальний пакет може містити набір предметів для конструювання, креслення, малювання, а також методичні вказівки для викладачів, що включають перелік видів занять і порядок їх проведення, поради з організації індивідуальної роботи або роботи в малих групах, рекомендації з організації лабораторних і практичних робіт, дидактичних ігор, а також запитання для самоперевірки [11].

Згідно з новими стандартами вищої освіти були внесені зміни в навчальні плани з багатьох дисциплін, в тому числі і фармакології. Все більша частка інформації має бути опрацьована студентами самостійно. Для полегшення сприйняття студентами великої кількості матеріалу ми запропонували нашим студентам не тільки базовий рівень методичних рекомендацій, але і вирішили дещо урізноманітнити подачу матеріалу. Студенти мають змогу перевірити свої знання різнорівневими тестами і задачами, крім того, ми пропонуємо нашим студентам розв’язати фармакологічні кросворди. До кожної теми є пакет фотографій з лікарським засобами в різних формах, що безперечно сприятиме кращому запам’ятовуванню матеріалу. 
Висновки. Таким чином, сучасні підходи до викладання фармакології можуть та повинні вдало поєднувати як новітні, так і добре відомі дидактичні прийоми, методи активізації навчально-пізнавальної діяльності слухачів (пояснювально-ілюстративні, репродуктивні, частково-пошукові, мнемотехнічні тощо). Вони органічно вписуються в педагогічний процес, доповнюють та урізноманітнюють викладання, а також відповідають умовам педагогічного середовища вищих навчальних закладів.

Творчі підходи до подання та перевірки засвоєння навчального матеріалу дозволяють студентам

\section{Список літератури}

1. Дичківська І. М. Інноваційні педагогічні технології. Навчальний посібник / I. М. Дичківська. - К. : Академвидав, 2015.- 307 с.

2. Закон України “Про вищу освіту” від 01.07.2014 р. № 1556-VII. - Режим доступу : http://zakon2.rada.gov.ua/ laws/show/1556-18.

3. Автомонов П. П. Дидактика вищої школи : підручник / П. П. Автомонов. - К. : ВПЦ “Київський університет, 2008. - 368 с.

4. Малафіїк I. В. Дидактика. Навчальний посібник / I. В. Малафіїк. - К. : Кондор, 2009. - 406 с.

5. Ортинський В. Л. Педагогіка вищої школи. Навчальний посібник для студентів вищих навчальних закладів / В. Л. Ортинський.- К. : Центр учбової літератури, 2009. -472 c. досягти максимуму повноти і глибини розуміння предмета, що вивчається. Такий підхід дає змогу гармонізувати співвідношення навчання під керівництвом викладача, застосувати інформаційні технології та вдосконалити роботу студентів, що буде сприяти розвитку самостійного мислення, адаптацію до складних та нетипових ситуацій, ініціативність, самостійність у прийнятті рішень, творчий підхід до розв'язання проблем, які неодмінно будуть виникати в клінічній практиці лікаря будь-якої спеціальності.

6. Кривошей В. Активізація інноваційних підходів підготовки фахівців з обліку, аудиту та фінансів / В. Кривошей, А. Мазуркевич. - Х. : ХДУХТ, 2010. - 42 с.

7. Бойко 3. В. Використання мнемотехнічних прийомів при запам'ятовуванні географічних об’ єктів, їх назв та образів / 3. В. Бойко // Науковий вісник Донбасу. 2011. - № 4. - С. 23-27.

8. Маклаков А. Г. Загальна психологія / А. Г. Маклаков. - СПб. : Питер, 2001. - 234 с.

9. Зиганов М. Мнемотехніка. Запам'ятовування на основі візуального мислення / М. Зиганов, В. Козаренко. - К. : Школа раціонального читання, 2001. - 304 с.

10. Цимбалюк I. М. Психологія. Навчальний посібник / I. М. Цимбалюк. - К. : ВД “Професіонал”, 2006. - 216 с.

11. Бугрій О. Активізація навчального процесу в зарубіжній вищій школі / О. Бугрій // Вища школа. 2008. - № 5. - C. 70-78. 